\title{
The occurrence of Austrodiplostomum compactum (Lutz, 1928) (Digenea: Diplostomidae) metacercariae in the eyes of loricariid fish (Siluriformes: Osteichthyes: Loricariidae) from Brazil
}

\author{
E.O.P. Zica ${ }^{1}$, H. Brandão ${ }^{1}$, C.H. Zawadzki ${ }^{2}$, A.B. Nobile ${ }^{1}$, \\ E.D. Carvalho ${ }^{3}$ and R.J. da Silva ${ }^{4 *}$ \\ ${ }^{1}$ Zoology Postgraduate Course, Instituto de Biociências, Universidade \\ Estadual Paulista, Botucatu, São Paulo State, Brazil: ${ }^{2}$ Departament of \\ Biology, Centro de Ciências Biológicas, Universidade Estadual de Maringá, \\ Paraná State, Brazil: ${ }^{3}$ Department of Morphology, Instituto de Biociências, \\ Universidade Estadual Paulista, Botucatu, São Paulo, Brazil: ${ }^{4}$ Department \\ of Parasitology, Instituto de Biociências, Universidade Estadual Paulista, \\ Botucatu, São Paulo, Brazil
}

(Accepted 16 March 2010; First Published Online 12 May 2010)

\begin{abstract}
The aim of this study was to report the occurrence of Austrodiplostomum compactum metacercariae in the eyes of 98 specimens of loricariid fish (Hypostomus ancistroides, H. hermanni, H. iheringii, H. margaritifer, H. regani, H. strigaticeps, Hypostomus sp. and Megalancistrus parananus) from the Chavantes reservoir $\left(23^{\circ} 07^{\prime} 36^{\prime \prime} \mathrm{S}\right.$ and $\left.49^{\circ} 37^{\prime} 35^{\prime \prime} \mathrm{W}\right)$ located in the rio Paranapanema, upper Paraná river basin, municipality of Ipaussu, São Paulo State, Brazil. Fish were collected from October 2007 to February 2009 using nylon monofilament gill nets and transported to the field laboratory where they were euthanized and the eyes were taken and examined under a stereomicroscope. Hypostomus ancistroides and M. parananus were not infected by this diplostomid. Hypostomus hermanni and $H$. margaritifer were represented by only one specimen but both had a high intensity of $A$. compactum metacercarie (27 and 35, respectively). Hypostomus strigaticeps $(n=45)$ and $H$. iheringii $(n=28)$ were the most representative specimens and the prevalence, mean intensity of infection and mean abundance were $24.4 \%, 10.3$ and 2.7 , and $64.2 \%, 13.1$ and 8.4, respectively. No correlation was observed between the intensity of infection and the standard length $(r=-0.223 ; P=0.827)$ and weight $(r=0.03 ; P=0.779)$ of studied fish. Similarly, linear regression among these variables showed a poor correlation and indicated that the infection by $A$. compactum metacercariae occurs similarly in small and large fish specimens. A seasonal pattern of infection was not observed. Hypostomus hermanni, H. iheringii, H. margaritifer and H. strigaticeps were new hosts recorded for $A$. compactum metacercariae. A review of morphometric data of $A$. compactum metacercariae is presented.
\end{abstract}

*E-mail: reinaldo@ibb.unesp.br 


\section{Introduction}

Austrodiplostomum compactum (Lutz, 1928) (Niewiadomska, $2002 a, b$ ) is a digenetic trematode of the order Strigeoidea whose metacercariae (fig. 1) occur in the eyes of a wide variety of fish species (Ostrowski-Núñez, 1982; Pineda-López, 1985; Osorio-Sarabia et al., 1987; Garcia et al., 1993; Kohn et al., 1995; Pavanelli et al., 1997; Almeida, 1998; Silva-Souza, 1998; Martins et al., 1999, 2002; Santos et al., 2002; Paes et al., 2003; Machado et al., 2005; Novaes et al., 2006; Yamada et al., 2008; Zica et al., 2009). The metacercariae of these digeneans can infect the vitreous humour (Scholtz et al., 1995; Silva-Souza, 1998; Amato et al., 2001) and, more rarely, the brains of the intermediate fish hosts (Ostrowski-Núñez, 1982; Silva-Souza, 1998; Amato et al., 2001).

In Brazil, A. compactum metacercariae have been reported previously in fishes of the orders Characiformes, Serrasalmus maculatus (Kner, 1858) (Characidae), Hoplias malabaricus (Bloch, 1794) (Erythrinidae) and Schizodon borellii (Boulenger, 1900) (Anostomidae); Siluriformes, Hypostomus regani (Ihering, 1905) (Loricariidae) and Auchenipterus osteomystax (Miranda-Ribeiro, 1918) (Auchenipteridae); and Perciformes, Cichla ocellaris (Block \& Schneider, 1801), Cichla monoculus (Spix \& Agassiz, 1831), Crenicichla britskii (Kullander, 1982), Cichlasoma paranaense (Kullander, 1983), Geophagus brasiliensis (Quoy \& Gaimard, 1824), Satanoperca pappaterra (Heckel, 1840) (Cichlidae) and Plagioscion squamosissimus (Heckel, 1840) (Scianidae) (see Machado et al., 2005; Novaes et al., 2006; Yamada et al., 2008; Zica et al., 2009).

Loricariid fish (family Loricariidae) have scarcely been examined for diplostomids. Amato et al. (2001) found diplostomid metacercariae of an undetermined species on the surface of, and within, the kidney ducts, on the surface of the liver and the peritoneum, and within the abdominal cavity and brain of Loricariichthys anus (Valenciennes, 1840) from Rio Grande do Sul State, Brazil.
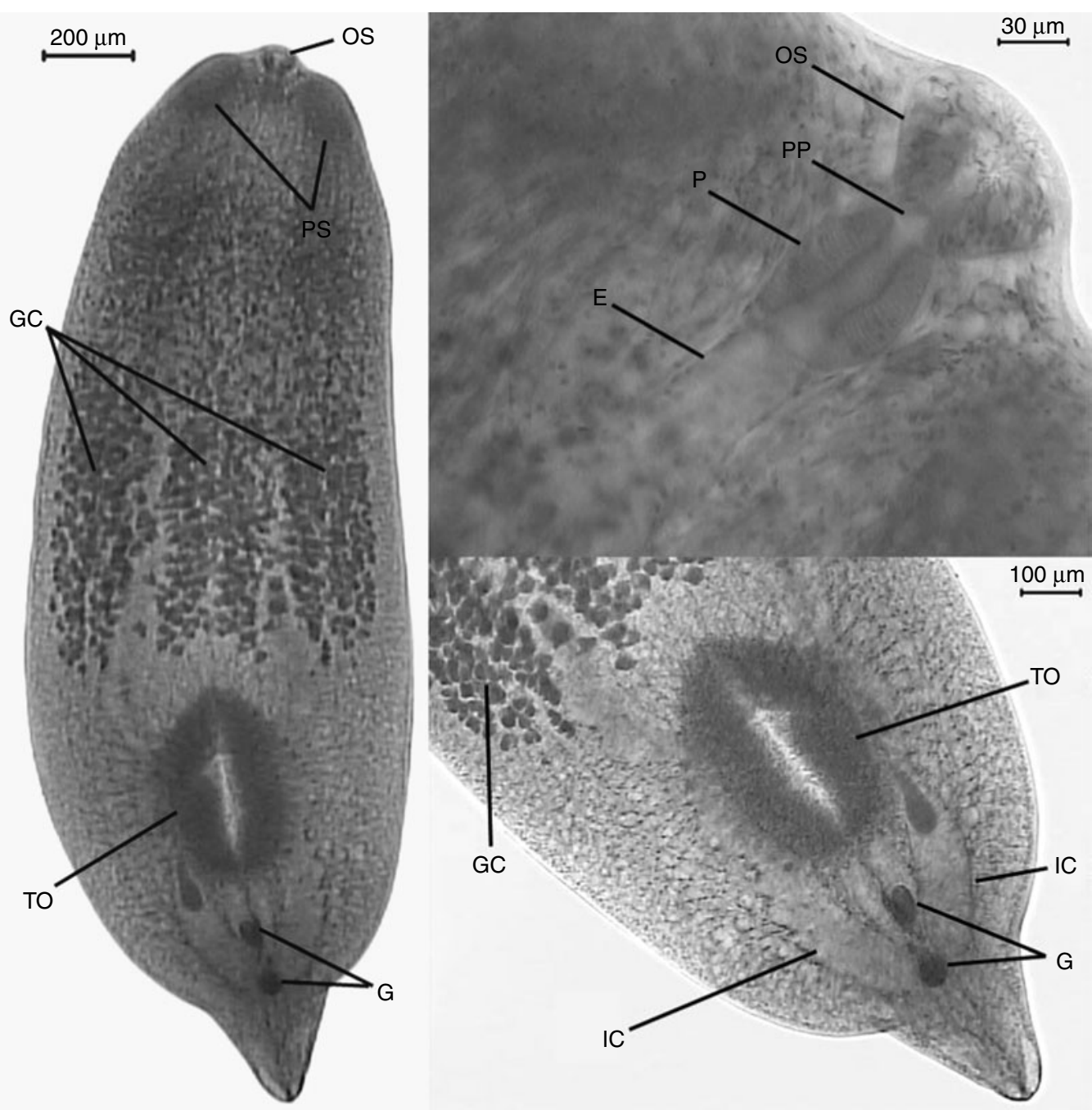

Fig. 1. Specimen of Austrodiplostomum compactum metacercaria (Digenea: Diplostomidae). E, oesophagus; G, gonads; GC, gland cells; IC, intestinal caeca; OS, oral sucker; P, pharynx; PP, prepharynx; PS, pseudo-suckers; TO, trybocitic organ. 
Hypostomus regani was recently recorded as a host for A. compactum metcercariae (Yamada et al., 2008; Zica et al., 2009). However, no other studies of infection by these metacercariae in loricariid fish have been conducted.

Based on the previous report on the occurrence of A. compactum metacercariae in fish of the genus Hypostomus (Yamada et al., 2008; Zica et al., 2009), the aim of the present study was to investigate the occurrence of infection by $A$. compactum metacercariae in the eyes of loricariid fish from Chavantes reservoir (see fig. 2), in the upper Paraná river basin, in the municipality of Ipaussu, São Paulo State, Brazil, in order to determine whether the reports of Yamada et al. (2008) and Zica et al. (2009) are incidental cases or whether these metacercariae are commonly distributed among loriicarid fish.

\section{Materials and methods}

The study was carried out from October 2007 to February 2009 in the Chavantes reservoir (fig. 2), in the upper Paraná basin, municipality of Ipaussu, São Paulo State, Brazil. The Chavantes reservoir is located in the middle of the Paranapanema River, between the states of São Paulo and Paraná (Sampaio, 1944). The Chavantes hydroelectric power plant has an installed power capacity of approximately $414 \mathrm{MW}$. The dam is located at $480 \mathrm{~m}$ altitude, and its hydrographic basin includes large rivers such as the Paranapanema, Itararé and Verde. It is a reservoir of the accumulation basin type, with maximum depth of $70-90 \mathrm{~m}$ near the barrage, operational useful maximum quota of $474 \mathrm{~m}$, total volume of $9.410 \times 10^{6} \mathrm{~m}^{3}$, an area of $27,500 \mathrm{~km}^{2}$ and $400 \mathrm{~km}^{2}$ water mirror in its operational maximum quota (Duke Energy, 2010).

Fish were collected using a gillnet of nylon monofilament installed 2 days/month in two sites (Site 1: $23^{\circ} 07^{\prime} 30.71^{\prime \prime} \mathrm{S}$ and $49^{\circ} 37^{\prime} 37.31^{\prime \prime} \mathrm{W}$; Site 2: $23^{\circ} 07^{\prime} 59.23^{\prime \prime} \mathrm{S}$ and $49^{\circ} 36^{\prime} 10^{\prime \prime} \mathrm{W}$ ) of the reservoir (fig. 2), from 17.00 hours until 07.00 hours the following day, totalling $14 \mathrm{~h}$ of exposure. The collected loricariid fish specimens were transported to the field laboratory where they were measured $(\mathrm{cm})$ and weighed $(\mathrm{g})$. All data were presented as mean \pm standard deviation (minimum maximum) values. Then the fish were euthanized and the eyes were taken and examined under a stereomicroscope. Metacercariae found in the vitreous humour were fixed in AFA (alcohol-formaldehydeacetic acid) solution under slight pressure of a coverslip for $10 \mathrm{~min}$, and then transferred to $70 \%$ alcohol for further processing.

Identification of $A$. compactum metacercariae was based on the morphological studies of Kohn et al. (1995) and Zica et al. (2009). The main characteristics of A. compactum metacercariae (fig. 1) were: foliaceous body, slightly concave in the ventral face; small conical segment in the posterior region; small subterminal oral sucker; two lateral pseudosuckers in the anterior region; oval pharynx; short oesophagus; intestinal caeca ending near the posterior region; oval tribocytic organ; gland cells occupying most of the anterior region, extending from the beginning of intestinal caeca in the anterior region to the tribocytic organ (Kohn et al., 1995; Santos et al., 2002; Paes et al., 2003; Novaes et al., 2006; Zica et al., 2009) (fig. 1). Morphometric data of A. compactum metacercariae are summarized in table 1.

Fish voucher specimens were deposited at the Ichthyological Collection of Núcleo de Pesquisa em Limnologia, Ictiologia e Aquicultura (NUP) of the Universidade Estadual de Maringá, municipality of Maringá, Paraná State, Brazil and at the Laboratório de Biologia e Genética de Peixes, Instituto de Biociências (LBP) da Universidade Estadual Paulista, municipality of Botucatu, São Paulo State, Brazil. Metacercariae of A. compactum were

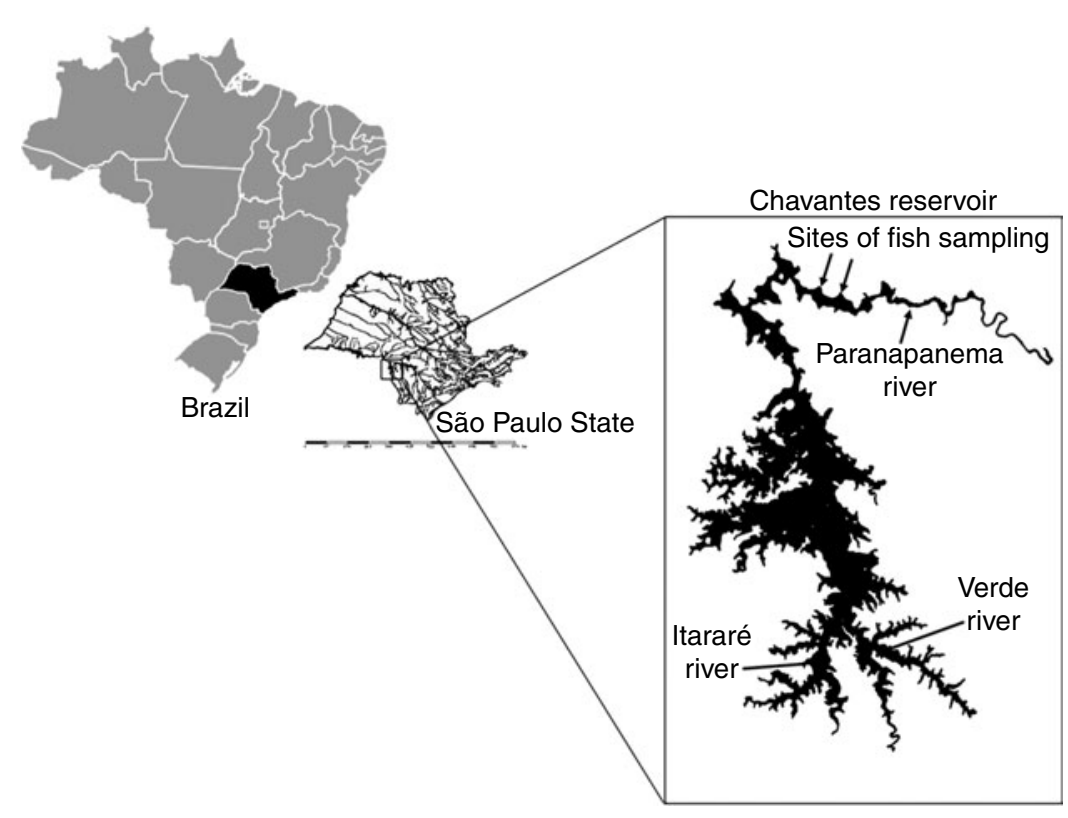

Fig. 2. Sites of loricariid fish (Siluriformes: Osteichthyes: Loricariidae) sampling in the Chavantes reservoir, in the upper Paraná river basin, municipality of Ipaussu, São Paulo State, Brazil. 
Table 1. Morphometric data of Austrodiplostomum compactum (Digenea: Diplostomidae) metacercariae. Measurements are in micrometres; ranges are followed by means in parentheses.

\begin{tabular}{|c|c|c|c|c|c|c|c|}
\hline \multirow[b]{2}{*}{ Host } & \multirow{2}{*}{$\begin{array}{c}\begin{array}{c}\text { Kohn et al. } \\
(1995)\end{array} \\
\begin{array}{c}\text { Plagioscion } \\
\text { squamosissimus }\end{array}\end{array}$} & \multicolumn{2}{|c|}{$\begin{array}{l}\text { Santos et al. } \\
\quad(2002)\end{array}$} & \multirow{2}{*}{$\begin{array}{c}\begin{array}{c}\text { Paes et al. } \\
(2003)\end{array} \\
\text { Plagioscion } \\
\text { squamosissimus }\end{array}$} & \multirow{2}{*}{$\begin{array}{c}\begin{array}{c}\text { Novaes et al. } \\
(2006)\end{array} \\
\begin{array}{c}\text { Geophagus } \\
\text { brasiliensis }\end{array}\end{array}$} & \multirow{2}{*}{$\begin{array}{c}\begin{array}{c}\text { Zica et al. } \\
(2009)\end{array} \\
\begin{array}{c}\text { Hypostomus } \\
\text { regani }\end{array}\end{array}$} & \multirow{2}{*}{$\begin{array}{c}\text { Total variation } \\
\text { for the species } \\
-\end{array}$} \\
\hline & & $\begin{array}{c}\text { Plagioscion } \\
\text { squamosissimus }\end{array}$ & $\begin{array}{l}\text { Cichla } \\
\text { ocellaris }\end{array}$ & & & & \\
\hline $\begin{array}{l}\text { Number of } \\
\text { specimens }\end{array}$ & 14 & 20 & 20 & - & 5 & 10 & - \\
\hline Length & $\begin{array}{l}1470-2740 \\
(2170)\end{array}$ & $\begin{array}{l}880-1840 \\
(1434)\end{array}$ & $\begin{array}{l}960-2480 \\
(1462)\end{array}$ & $\begin{array}{c}1301-2376 \\
(1911)\end{array}$ & $\begin{array}{l}1584-1947 \\
(1800)\end{array}$ & $\begin{array}{l}1570-2281 \\
(1988)\end{array}$ & $880-2740$ \\
\hline $\begin{array}{l}\text { Length of conical } \\
\text { segment }(\mu \mathrm{m})\end{array}$ & $\begin{array}{c}41-97 \\
(77)\end{array}$ & - & - & - & - & - & $41-97$ \\
\hline \multicolumn{8}{|l|}{ Oral sucker } \\
\hline Length & $\begin{array}{c}41-97 \\
(77)\end{array}$ & $\begin{array}{c}44-90 \\
(65)\end{array}$ & $\begin{array}{l}40-98 \\
(68)\end{array}$ & $\begin{array}{l}51-87 \\
(71)\end{array}$ & $\begin{array}{l}45-83 \\
(59)\end{array}$ & $\begin{array}{c}69-102 \\
(91)\end{array}$ & $40-102$ \\
\hline Width & $\begin{array}{l}56-116 \\
(79)\end{array}$ & $\begin{array}{c}40-64 \\
(52)\end{array}$ & $\begin{array}{c}30-98 \\
(56)\end{array}$ & $\begin{array}{l}51-92 \\
(73)\end{array}$ & $\begin{array}{c}54-77 \\
(68)\end{array}$ & $\begin{array}{c}75-99 \\
(84)\end{array}$ & $30-116$ \\
\hline \multicolumn{8}{|l|}{$\begin{array}{l}\text { Lateral } \\
\quad \text { pseudosucker (1) }\end{array}$} \\
\hline Width & - & - & - & - & - & $\begin{array}{c}68-157 \\
(118)\end{array}$ & $65-146$ \\
\hline \multicolumn{8}{|l|}{$\begin{array}{l}\text { Lateral } \\
\quad \text { pseudosucker (2) }\end{array}$} \\
\hline Length & - & - & - & - & - & $\begin{array}{c}78-168 \\
(131)\end{array}$ & $78-168$ \\
\hline Width & - & - & - & - & - & $\begin{array}{l}85-146 \\
(119)\end{array}$ & $85-146$ \\
\hline \multicolumn{8}{|l|}{ Prepharynx } \\
\hline Length & - & $\begin{array}{c}2-10 \\
(6)\end{array}$ & $\begin{array}{l}4-20 \\
(9)\end{array}$ & - & - & - & $2-20$ \\
\hline Width & - & $\begin{array}{c}10-24 \\
(17)\end{array}$ & $\begin{array}{c}16-38 \\
(23)\end{array}$ & - & - & - & $10-38$ \\
\hline Width & - & - & - & $\begin{array}{c}29-53 \\
(39)\end{array}$ & - & - & $29-53$ \\
\hline \multicolumn{8}{|l|}{ Tribocytic organ } \\
\hline Length & $\begin{array}{l}326-650 \\
(507)\end{array}$ & $\begin{array}{l}200-600 \\
(285)\end{array}$ & $\begin{array}{l}200-496 \\
(308)\end{array}$ & $\begin{array}{l}205-554 \\
\quad(401)\end{array}$ & $\begin{array}{l}422-434 \\
\quad(428)\end{array}$ & $\begin{array}{c}287-414 \\
(373)\end{array}$ & $200-650$ \\
\hline Width & $\begin{array}{l}251-500 \\
(370)\end{array}$ & $\begin{array}{l}160-232 \\
(182)\end{array}$ & $\begin{array}{c}120-320 \\
(180)\end{array}$ & $\begin{array}{l}127-347 \\
(243)\end{array}$ & $\begin{array}{l}220-319 \\
(258)\end{array}$ & $\begin{array}{l}178-310 \\
(243)\end{array}$ & $127-500$ \\
\hline
\end{tabular}

deposited in the Coleção Helmintológica (CHIBB) of the Departamento de Parasitologia, Instituto de Biociências, Universidade Estadual Paulista, municipality of Botucatu, São Paulo State, Brazil.

Mean intensity of infection and mean abundance were calculated according to Bush et al. (1997). The MannWhitney test was used to examine whether there are effects of sample site on the parasitism. The effect of seasonalilty on the parasitism was examined using pooled data among all host species. Seasons were compared with the Kruskall-Wallis test. Spearmann's correlation test was used to evaluate the correlation between the intensity of infection and the fish standard length and weight using the software SigmaStat 3.0 (Jandel Corporation, San Rafael, California, USA).

\section{Results}

Ninety-eight specimens of loricariid fish were collected. These include Hypostomus ancistroides (Ihering, 1911), H. hermanni (Ihering, 1905), H. iheringii (Regan, 1908), H. margaritifer (Regan, 1908), H. regani, H. strigaticeps (Regan, 1908), Hypostomus sp. and Megalancistrus parananus (Peters, 1881) (table 2).

Metacercariae of $A$. compactum were found in the eyes of 34 specimens of the studied fish (overall 
Table 2. Data on infection by Austrodiplostomum compactum metacercariae in the eyes of loricariid fish sampled from the Chavantes reservoir, in the upper Paraná river basin, municipality of Ipaussu, São Paulo State, Brazil.

\begin{tabular}{|c|c|c|c|c|c|c|}
\hline Fish species & $\begin{array}{l}\text { Standard length }(\mathrm{cm}) \\
\text { Mean } \pm \text { SD (range) }\end{array}$ & $\begin{array}{c}\text { Weight (g) } \\
\text { Mean } \pm \text { SD (range) }\end{array}$ & $\mathrm{IF} / \mathrm{TF}$ & $\begin{array}{l}\text { Mean intensity } \\
\text { of infection }\end{array}$ & $\begin{array}{c}\text { Mean } \\
\text { abundance }\end{array}$ & $\mathrm{CHIBB}^{* *}$ \\
\hline $\begin{array}{l}\text { Hypostomus ancistroides } \\
\text { LBP 7581, NUP 6787* }\end{array}$ & $\begin{array}{l}12.9 \pm 0.7 \\
(10.4-17.3)\end{array}$ & $\begin{array}{c}55.9 \pm 6.4 \\
(32.7-102.4)\end{array}$ & $0 / 10$ & - & - & - \\
\hline $\begin{array}{l}\text { Hypostomus hermanni } \\
\text { LBP } 7582\end{array}$ & 9.4 & 36.2 & $1 / 1$ & 27 & 27 & 4721 \\
\hline $\begin{array}{l}\text { Hypostomus iheringii }^{+} \\
\text {LBP } 7578,7583\end{array}$ & $\begin{array}{l}12.7 \pm 0.5 \\
(7.2-19.6)\end{array}$ & $\begin{array}{c}72.7 \pm 8.3 \\
(10.4-218.6)\end{array}$ & $18 / 28$ & $\begin{array}{c}13.1 \pm 3.2 \\
\quad(1-48)\end{array}$ & $\begin{array}{l}8.4 \pm 2.4 \\
(0-48)\end{array}$ & $4722-4739$ \\
\hline $\begin{array}{l}\text { Hypostomus margaritifer } \\
\text { NUP } 6785\end{array}$ & 19 & 203.2 & $1 / 1$ & 35 & 35 & 4740 \\
\hline $\begin{array}{l}\text { Hypostomus regani } \\
\text { LBP } 7580\end{array}$ & $\begin{array}{c}18.2 \pm 2.1 \\
(14.2-21.4)\end{array}$ & $\begin{array}{l}153.8 \pm 44.1 \\
(74.3-226.3)\end{array}$ & $1 / 3$ & 10 & $\begin{array}{c}3.3 \pm 3.3 \\
(0-10)\end{array}$ & 4741 \\
\hline $\begin{array}{l}\text { Hypostomus strigaticeps }^{\dagger} \\
\text { LBP } 7577\end{array}$ & $\begin{array}{l}13.7 \pm 0.4 \\
(7.8-20.1)\end{array}$ & $\begin{array}{l}88.2 \pm 7.7 \\
(14.3-254)\end{array}$ & $11 / 45$ & $\begin{array}{l}10.3 \pm 2.4 \\
(2-25)\end{array}$ & $\begin{array}{l}2.7 \pm 0.9 \\
(0-25)\end{array}$ & $4742-4752$ \\
\hline $\begin{array}{l}\text { Hypostomus sp. } \\
\text { NUP } 6784,6787\end{array}$ & $\begin{array}{l}12.3 \pm 0.7 \\
(10-14.6)\end{array}$ & $\begin{array}{l}59.5 \pm 11.3 \\
(24.8-103.8)\end{array}$ & $2 / 5$ & $\begin{array}{l}17.5 \pm 16.5 \\
(1-34)\end{array}$ & $\begin{array}{l}7 \pm 6.8 \\
(0-34)\end{array}$ & $4753-4754$ \\
\hline $\begin{array}{l}\text { Megalancistrus parananus } \\
\text { LBP } 7579\end{array}$ & $\begin{array}{l}18.1 \pm 2.4 \\
(12.6-26.5)\end{array}$ & $\begin{array}{l}234.2 \pm 98.9 \\
(57.1-610.9)\end{array}$ & $0 / 5$ & - & - & - \\
\hline
\end{tabular}

IF/TF, number of infected fish/total number of fish.

* Numbers in the first column are the accession numbers of voucher host species in the Ichthyological Collection of the Núcleo de Pesquisa em Limnologia, Ictiologia e Aquicultura (NUP) of the Universidade Estadual de Maringá, Municipality of Maringá, Paraná State, Brazil and at the Laboratório de Biologia e Genética de Peixes, Instituto de Biociências (LBP) da Universidade Estadual Paulista, Municipality of Botucatu, São Paulo State, Brazil.

${ }^{* *}$ Numbers in the last column are the accession numbers of voucher helminth species in the CHIBB (Coleção Helmintológica of the Departamento de Parasitologia, Instituto de Biociências, Universidade Estadual Paulista, Municipality of Botucatu, São Paulo State, Brazil).

${ }^{+}$New host record for Austrodiplostomum compactum metacercariae.

prevalence $=34.7 \%$ ). Only $H$. ancistroides and $M$. parananus were not infected by this diplostomid. Hypostomus hermanni and $H$. margaritifer were represented by only one specimen each but both had a high intensity of infection by $A$. compactum metacercariae (27 and 35 metacercariae, respectively). Infection was detected in $H$. regani and Hypostomus sp. The former had one specimen parasitized with 10 metacercariae in the eyes and the latter had two specimens parasitized with one and 34 diplostomids (table 2).

Hypostomus strigaticeps $(n=45)$ and H. iheringii $(n=28)$ were the species with the highest numbers of fish sampled in the study. For these species, the prevalence of infection was $24.4 \%$ and $64.2 \%$, respectively. Hypostomus iheringii presented with a slightly larger number of parasites. However, abundance was higher in $H$. iheringii (13.1) than in $H$. strigaticeps (10.3) (table 2).

There was no correlation between the intensity of infection and the fish standard length $(n=98$; $r=-0.0223 ; P=0.827)$ or weight $(n=98 ; r=0.0286$; $P=0.779)$, and there was no effect of sample site on the parasitism $(P=0.766)$. Also, a seasonal pattern of infection was not observed $(P=0.815)$, although a slight tendency for an increase during autumn could be detected (fig. 3).

Hypostomus hermanni, $H$. iheringii, $H$. margaritifer and $H$. strigaticeps were new hosts recorded for $A$. compactum metacercariae.

\section{Discussion}

The present study reports the occurrence of A. compactum metacercariae in six loricariid fish species from the Chavantes reservoir, in the upper Paraná river basin, municipality of Ipaussu, with a record of four new hosts. The metacercariae of this diplostomid have low specificity since many intermediate fish hosts have already been found to be infected with $A$. compactum metacercariae in the eyes or brain, mainly in Brazil

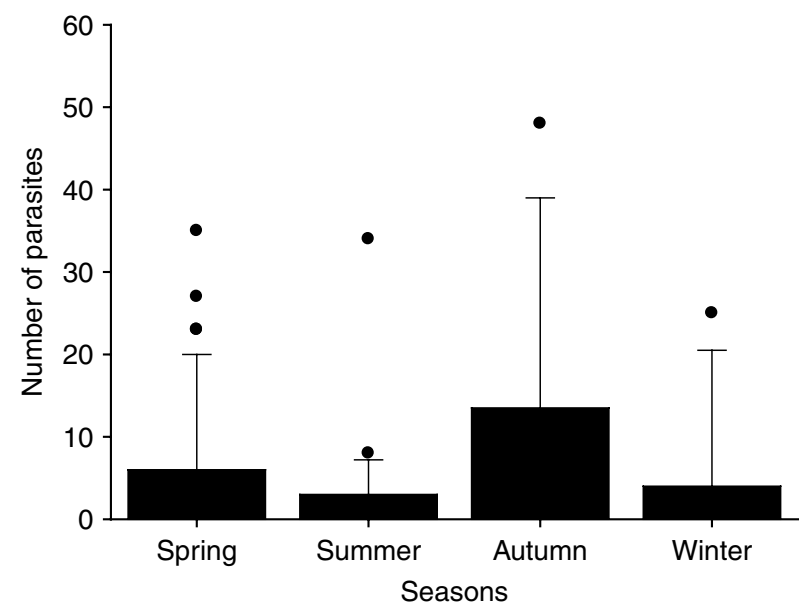

Fig. 3. Box plot of the number of Austrodiplostomum compactum metacercariae in the loricariid fish (Siluriformes: Osteichthyes: Loricariidae) sampled in the Chavantes reservoir, in the upper Paraná river basin, municipality of Ipaussu, São Paulo State, Brazil in different seasons. All median values were zero. The superior limit of the boxes represents the 75th percentile, error bars are 90th percentile and circles are outliers. No statistical differences were observed between the seasons $(P=0.815)$. 
(Machado et al., 2005; Novaes et al., 2006; Yamada et al., 2008; Zica et al., 2009). However, the infection by A. compactum metacercariae is rarely observed in loricariid fish (Amato et al., 2001; Yamada et al., 2008; Zica et al., 2009) and is restricted to Brazilian fishes.

Pojmanska \& Chabros (1993) demonstrated that the prevalence of diplostomids was significantly lower in native fishes and higher for introduced species. In fact, it has been further demonstrated that the introduced species $P$. squamosissimus presents high infection levels by A. compactum metacercariae (Kohn et al., 1995; Santos et al., 2002; Paes et al., 2003; Machado et al., 2005). Similar data were observed by Machado et al. (2005) in several fishes from the floodplain of the upper Paraná river basin, Brazil. These authors hypothesized that this metacercaria species was introduced together with the hosts and is utilizing native fish from the region as alternative second intermediate hosts (Machado et al., 2005). As highlighted by several authors (see Zica et al., 2009 and references therein), progressively more native fishes have been reported as intermediate hosts for $A$. compactum, which appears to corroborate the hypothesis presented by Machado et al. (2005).

Eight loricariid fish species collected from two sites of the Chavantes reservoir were sampled in this study. Only two species (H. ancistroides and $M$. parananus) were not infected with $A$. compactum metacercariae. Zica et al. (2009) suggested that the infection by $A$. compactum metacercariae may be associated with environmental factors and biology of the hosts, as the first intermediate host is an aquatic snail and the loricariid specimens are usually bottom fish (Garavello \& Garavello, 2004). The infection can occur because both (first and second intermediate hosts) use the same habitats, which increases the possibility of the encounter between host and parasite. In this way, the absence of infection in $H$. ancistroides and $M$. parananus may be related to some unknown ecological aspects of these hosts. In the case of $H$. ancistroides, it is known that this species lives preferentially under the marginal vegetation in the river (C.H. Zawadzki, pers. obs.) or under wood debris (Casatti, 2005), which could explain the absence of parasites in this species. Future studies will be conducted to clarify this.

\section{Acknowledgements}

We thank to FAPESP (Fundação de Amparo à Pesquisa do Estado de São Paulo), for financial support (2007/58246-4). We are also grateful to Kristin Nicole Taylor, from Weill Cornell Medical College, New York, USA, for the English review of the manuscript.

\section{References}

Almeida, S.C. (1998) Aspectos ecológicos dos endohelmintos parasitos de Hoplias malabaricus (Bloch, 1974) (Osteichthyes-Erythrinidae) do alto rio Paraná, região de Porto Rico, Paraná, Brasil. MSc Thesis, Departamento de Biologia, Universidade Estadual de Maringá, Maringá.
Amato, S.B., Amato, J.F.R. \& Albrecht, M. (2001) Metacercárias livres de diplostomídeos (Digenea, Diplstomidae) em Loricariichthys anus (Val., 1840) (Siluriformes, Loricariidae) do Estado de Rio Grande do Sul, Brasil. Parasitologia al Dia 25, 24-29.

Bush, A.O., Lafferty, K.D., Lotz, J.M. \& Shostak, A.W. (1997) Parasitology meets ecology on its terms: Margolis et al. revisited. Journal of Parasitolology 83, 575-583.

Casatti, L. (2005) Fish assemblage structure in a first order stream, southeastern Brazil: longitudinal distribution, seasonality, and micorhabitat diversity. Biota Neotropica 5. Available at http://www.biotaneotro pica.org.br/v5n1/pt/abstract?article + BN02505012005 (accessed 10 February 2009).

Duke Energy (2010) Usina Chavantes (CHV). Available at http:/ / www.duke-energy.com.br/usinas/informacoe stecnicas/pop_chavantes.asp (accessed 21 April 2010).

Garavello, J.C. \& Garavello, J.P. (2004) Spatial distribution and interaction of four species of the catfish genus Hypostomus Lacépède with bottom of rio São Francisco, Canindé do São Francisco, Sergipe, Brazil (Pisces, Loricariidae, Hypostominae). Brazilian Journal of Biology 64, 591-598.

Garcia, M.L.J., Osório-Sarabia, D. \& Constantino, F. (1993) Prevalência de los parasitos y lãs alteraciones histológicas que producen a las tilapias de la laguna de Amela Tecoman, Colima. Veterinaria México 24, 199-205.

Kohn, A., Fernandes, B.M.M. \& Baptista-Farias, M.F.D. (1995) Metacercariae of Diplostomum (Austrodiplostomum) compactum (Trematoda, Diplostomidae) in the eyes of Plagioscion squamosissimus (Teleostei, Sciaenidae) from the reservoir of the Hydroelectric Power Station of Itaipu, Brazil. Memórias do Instituto Oswaldo Cruz 90, 341-344.

Machado, P.M., Takemoto, R.M. \& Pavanelli, G.C. (2005) Diplostomum (Austrodiplostomum) compactum (Lutz, 1928) (Platyhelminthes, Digenea) metacercariae in fish from the floodplain of the Upper Paraná River, Brazil. Parasitology Research 97, 436-444.

Martins, M.L., Fujimoto, R.Y., Nascimento, A.A. \& Moraes, F.R. (1999) Ocorrência de Diplostomum sp. Nordmann, 1832 (Digenea: Diplostomidae) em Plagioscion squamosissimus (Heckel, 1840) proveniente do reservatório de Volta Grande, MG, Brasil. Acta Scientiarum 21, 263-266.

Martins, M.L., Paiva, A.M.F.C., Fujimoto, R.Y., Schalch, S.H.C. \& Colombano, N.C. (2002) Prevalência, sazonalidade e intensidade de infecção por Diplostomum (Austrodiplostomum) compactum Lutz, 1928 (Digenea, Diplostomidae), em peixes do reservatório de Volta Grande, Estado de Minas Gerais, Brasil. Acta Scientiarum 24, 469-474.

Niewiadomska, K. (2002a) Superfamily Diplostomoidea. pp. 159-166 in Gibson, D.I., Jones, A. \& Bray, R.A. (Eds) Keys to the Trematoda. Oxon, UK, CABI Publishing.

Niewiadomska, K. (2002b) Family Diplostomidae Poirier, 1886. pp. 167-196 in Gibson, D.I., Jones, A. \& Bray, R.A. (Eds) Keys to the Trematoda. Oxon, UK, CABI Publishing.

Novaes, J.L.C., Ramos, I.P., Carvalho, E.D. \& Silva, R.J. (2006) Metacercariae of Diplostomum compactum Lutz, 1928 (Trematoda, Diplostomidae) in the eyes of acara Geophagus brasiliensis Quoy \& Gaimard, 1824. Arquivo Brasileiro de Medicina Veterinária e Zootecnia 58, 1229-1231. 
Osorio-Sarabia, V., Pineda-López, R. \& SalgadoMaldonado, G. (1987) Fauna helmintológica de peces dulceacuícolas de Tabasco. Estudio preliminar. Universidad y Ciência 4, 5-31.

Ostrowski-Núñez, M. (1982) The life histories of Diplostomum (Austrodiplostomum) compactum (Lutz, 1928) Dubois, 1970 and D. (A.) mordax (Szidat and Nani, 1951) n. comb. in South América. Zoologischer Anzeiger 208, 393-404.

Paes, J.V.K., Santos, K.R., Carvalho, E.D. \& Silva, R.J. (2003) Ocorrência de metacercária de Diplostomum compactum (Trematoda, Diplostomidae) parasitando Plagioscion squamosissimus (Teleostei, Sciaenidae) proveniente do reservatório de Nova Avanhandava, Buritama, São Paulo. Arquivos do Instituto Biológico 70 (Suppl. 3), 383-387.

Pavanelli, G.C., Eiras, J.C. \& Takemoto, R.M. (1997) Doenças de peixes: profilaxia, diagnóstico e tratamento. 264 pp. Maringá, Nupélia.

Pineda-López, R. (1985) Infección por metacercárias (Plathyhelminthes: Trematoda) em peces de agua dulce de Tabasco. Universidad y Ciência 2, 47-60.

Pojmanska, T. \& Chabros, M. (1993) Parasites of common carp and three introduced cyprinid fish in pond culture. Acta Parasitologica 38, 101-108.

Sampaio, T. (1944) Relatório sobre os estudos efetuados nos rios Itapetininga e Paranapanema. Revista do Instituto Geográfico e Geológico 2, 30-81.
Santos, R.S., Pimenta, F.D.A., Martins, M.L., Takahashi, H.K. \& Marengoni, N.G. (2002) Metacercárias de Diplostomum (Austrodiplostomum) compactum Lutz, 1928 (Digenea, Diplostomidae) em peixes do rio Paraná, Brasil: Prevalência, sazonalidade e intensidade de infecção. Acta Scientiarum 24, 475-480.

Scholtz, T., Vargas-Vazquez, J., Moravec, F., VivasRodriguez, C. \& Mendonza-Franco, E. (1995) Metacercariae of trematodes of fishes from cenotes (sinkholes) of the Yucatan Peninsula, Mexico. Folia Parasitologica 42, 173-192.

Silva-Souza, A.T. (1998) Estudo do parasitismo de Plagioscion squamosissimus (Heckel, 1940) (Perciformes, Sciaenidae) por Diplostomum (Austrodiplostomum) compactum (Lutz, 1928) (Trematoda, Digenea) no rio Tibagi, PR. PhD thesis, UFSCar, São Carlos.

Yamada, F.H., Moreira, L.H. de A., Ceschini, T.L., Takemoto, R.M. \& Pavanelli, G.C. (2008) Novas ocorrências de metacercária de Austrodiplostomum compactum (Lutz, 1928) (Platyhelminthes: Digenea) parasito de olhos de peixes da bacia do rio Paraná. Revista Brasileira de Parasitologia Veterinária 17, 163-166.

Zica, E.O.P., Santos, K.R., Ramos, I.P., Zanatta, A.S., Carvalho, E.D. \& Silva, R.J. (2009) First case of an infection of the metacercariae of Austrodiplostomum compactum (Lutz, 1928) (Digenea, Diplostomidae) in Hypostomus regani (Ihering, 1905) (Siluriformes: Loricariidae). Pan-American Journal of Aquatic Sciences 4, 35-38. 